mentioned, have a score of over 99 per cent on two out of the three groups on the oil results. With the ammonia figures, the agreement is still better. Seventeen have a standing of 99 per cent or over on the meals Nos. 13-17; eight grade up to this figure on all of the first three groups, and four others have an efficiency of 99 per cent or better on two out of three of the groups.

Only one chemist remains who has not fallen below 99 per cent on either oil or ammonia in any of the groups so far analyzed. This man has hit the accepted average for oil four times and come within the two points allowable variation seven times on the first fifteen acceptable samples. His ammonia on these same samples were exact checks with the average twice and within the two-point limit ten times. This is certainly very satisfactory work.

The titers reported on Far No. 4 are, to use a homely expression, a fright. Something is radically wrong when two dozen chemists make as simple a determination as the titer, presumably following a precise set of directions, and get results varying over a range of $2^{\circ} \mathrm{C}$. The iodine value previously mentioned was bad enough, but this is the limit.

There is apparently among our members no proper appreciation of the absolute necessity for following exactly directions when using empirical methods. Unfortunately, very few of the determinations made on fats and oils are absolute. The literature is full of so-called constants which are worse than useless because the details of the methods by which they were obtained have not been given. The term "iodine value" is about as useful if unaccompanied by a statement of how obtained as a request to meet a friend in the New York Pennsylvania Station, without direction of when and where.

The work we have done so far on the fat and oil series shows one thing very conclusively and that is we need more of it. Our reputation as established by the splendid uniformity of results on oil and ammonia in meals will receive a severe jolt if it is noised abroad that we cannot be depended on to agree among ourselves to within $2^{\circ} \mathrm{C}$. on titers, 5 per cent on iodine numbers, or 3 per cent on T. F. A. You certainly cannot blame the unsatisfactory results on the samples, and I do not think they are chargeable to methods. Where, then? Very probably, as has been suggested, to the fact that too many chemists think their own particular procedure is a little better than the one they are asked to follow. Let us hope that the T. F. A. reports on the copra soap stock which goes out the middle of January shows some improvement over previous results and plan for next year to take these new lines of cooperative analytical work more seriously.

\section{THE CHEMIST IN INDUSTRY}

There are at least three different places for the chemist in most industries. One, probably the most important, is in connection with plant operation where trained men are needed; another is in connection with selling, where technical training is of advantage, and third, is in the laboratory itself, doing constructive research. From the viewpoint of American industry, it would seem that a great many more chemists are needed in the first two phases; that is, in plant operation and selling than are needed in the laboratory for research, and this is fortunate, for there are comparatively few men who by temperament, patience, and training are fitted to do, successfully, research work.

The question facing a young man fresh from his technical training is to determine in which phase of the industry he will make the greatest success and how to get started towards that particular field. Take for in- stance the young chemical graduate who has made up his mind that he will go into the plant operation or into the sales end. He may start in one or two different ways, either by attempting to get into the laboratory and work up thru the laboratory into the department towards which he is aiming, or he may take his educa tion as an asset and get a position in the industry along the lines which he desires to go and using his technical training to get him ahead. A great many men go thru the laboratory as a stepping-stone to the other departments, but I believe that a man will probably get farther in the end by going directly towards the object which he has in mind, as many men going into laboratory work become more or less side-tracked from the line of work for which perhaps they would be better equipped. Undoubtedly there is an opportunity in the chemical laboratory for a man to make this his specialty, but to be a success in this requires peculiar characteristics and training. I think a young man considering his future should be very certain that he is temperamentally and educationally equipped for research work in the industry before he starts into the work, with the idea of making that his particular field. Tns principal trouble with most college trained men in ciemistry at the present time is that they are trained to believe that research is the only field for them, when as a matter of fact the industry needs them in every field, and few will be successful in research. It seems to me that the biggest field for chemists is to fill the need of trained men in the industries themselves and not primarily as chemists.

\section{RANCIDITY AND ACIDITY OF OLIVE OILS Herbert Bailey, Southern Cotton Oil Company, Savannah, Georgia}

A large number of imported olive oils were tested for "rancidity" and free fatty acids by the writer a number of years ago while he was in charge of the fat and oil work of the U. S. Bureau of Chemistry. It is now quite commonly recognized that there is little or no relation between these two factors in a vegetable oil. True, both are doubtless due to a decomposition of the pure glycerides but they do not necessarily take place coincidently. The following data which has been culled from an old file of analyses shows pretty conclusively that an olive oil may be rancid as shown by the Kreis test and still comparatively low in F. F. A. Also that one may find high acid oils which do not give anything more than a very weak Kreis test.

Relation of F. F. A. to Ranctdity in Olive Oils

\begin{tabular}{|c|c|c|c|}
\hline $\begin{array}{l}\text { Rancidity } \\
\text { Kreis Test }\end{array}$ & F. F. A. & $\begin{array}{l}\text { Rancidity } \\
\text { Kreis Test }\end{array}$ & F. F. A. \\
\hline Weak & 1.0 & Weak & $x .3$ \\
\hline $\begin{array}{l}\text { Weak } \\
\text { Weak }\end{array}$ & $\begin{array}{l}1.2 \\
1.2\end{array}$ & Strong & $x .5$ \\
\hline Weak & 1.2 & Weak & $2 . \mathrm{I}$ \\
\hline Weak & I. 3 & Weak & 2.3 \\
\hline $\begin{array}{l}\text { Negative } \\
\text { Negative }\end{array}$ & $\begin{array}{l}0.9 \\
x .0\end{array}$ & $\begin{array}{l}\text { Strong } \\
\text { Strong }\end{array}$ & $\begin{array}{l}2.8 \\
2.9\end{array}$ \\
\hline $\begin{array}{l}\text { Negative } \\
\text { Negative }\end{array}$ & I. & Strong & $3 \cdot 1$ \\
\hline Negative & I. $x$ & Weak & 3.8 \\
\hline Negative & I.4 & Weak & 3.9 \\
\hline $\begin{array}{l}\text { Negative } \\
\text { Negative }\end{array}$ & $\begin{array}{l}1.5 \\
1.8\end{array}$ & Strong & 5.2 \\
\hline Negative & $\begin{array}{l}1.0 \\
4 . \mathrm{I}\end{array}$ & Weak & $\begin{array}{l}5.2 \\
5.3\end{array}$ \\
\hline Negative & 4.4 & Weak & 5.6 \\
\hline Negative & $\begin{array}{l}4.4 \\
\text { S.I }\end{array}$ & Strong & 5.6 \\
\hline Negative & 6.0 & Weak & 7.6 \\
\hline Negative & 8.0 & Strong & \\
\hline & $\ldots$ & Strong & 8.2 \\
\hline
\end{tabular}

To those accustomed to handling refined oils it may seem strange that the free acidity of these olive oils is so very high. It is a fact, however, that nearly all of this kind of oil imported contains many times as much free fatty acid as would be tolerated in a refined cottonseed or peanut oil. 